\title{
Density dependent foraging behaviour of sheep on alpine pastures: effects of scale
}

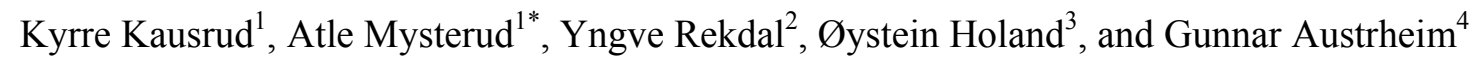

${ }^{1}$ Centre for Ecological and Evolutionary Synthesis (CEES), Department of Biology, University of Oslo, P.O. Box 1050 Blindern, N-0316 Oslo, Norway.

${ }^{2}$ Norwegian Institute of Land Inventory (NIJOS), Raveien 9, N-1430 Ås, Norway

${ }^{3}$ Institute for husbandry and aquaculture, Agricultural University of Norway, P.O. Box 5003, N-1432 Ås, Norway

${ }^{4}$ Department of Biology, Norwegian University of Science and Technology, N-7491

Trondheim, Norway.

"Corresponding author

e-mail: atle.mysterud@bio.uio.no

Tel: +47 228540 45, Fax: +47 22854605 
Kausrud, K., Mysterud, A., Rekdal, Y., Holand, Ø. and Austrheim, G. Density

dependent foraging behaviour of sheep on alpine pastures: effects of scale- Ecography $* *: * * * *$.

To understand the ecological effects of large herbivores, it is important to understand foraging behaviour and how this is affected by density. In this experiment, domestic sheep (Ovis aries) were kept at high ( 80 sheep per $\mathrm{km}^{2}$ ) and low (25 sheep per $\mathrm{km}^{2}$ ) population density in a landscape-scale experiment during summer in high mountain pastures in Hol, Norway. We predicted an increasing use of less preferred plant species or habitat types with increasing sheep population density. Foraging behaviour was investigated by direct observations of individually marked sheep on different spatial scales, and diet composition was also assessed with microhistological analysis of faecal samples from known individuals. We found that effects of density on foraging behaviour were scale-dependent, and only detected at the finest spatial scale, i.e. in diet choice. Use of the common grass species Deschampsia flexuosa, which provided the bulk forage (10-65\% of the diet), remained constant throughout the season at low densities, but increased significantly over time at high densities. Ewes ate a higher proportion of $D$. flexuosa than lambs. On a coarser spatial scale, neither patch (within vegetation type) nor habitat (vegetation type) selection was affected by density, but habitat selection differed depending on whether the sheep were grazing or resting. Our study thus provides evidence showing that density dependence in foraging behaviour occurs, but only at the finest spatial scale (diet choice). This result suggests a non-linear effect on the $D$. flexuosa population with an increase in sheep density: not only is an increasing number of sheep eating more, but each sheep also eat a larger proportion of $D$. flexuos a than at low densities. This thus provides a case showing that 
the ecological impact of grazers on plant populations may not be linearly related to herbivore density.

Kyrre Kausrud, Atle Mysterud (atle.mysterud@bio.uio.no), Centre for Ecological and Evolutionary Synthesis (CEES), Dept. of Biology, Univ. of Oslo, P.O. Box 1050 Blindern, N-0316 Oslo, Norway; Yngve Rekdal, Norwegian Institute of Land Inventory (NIJOS), Raveien 9, N-1430 Ås, Norway; Øystein Holand, Institute for husbandry and aquaculture, Agricultural University of Norway, P.O. Box 5003, N-1432 As, Norway; Gunnar Austrheim, Department of Biology, Norwegian University of Science and Technology, N-7491 Trondheim, Norway 
How foraging patterns of large herbivores vary depending on their population density is important for two main reasons: First, large herbivores may have huge impacts on ecosystem processes (reviews in Jefferies et al. 1994, Hobbs 1996), and how foraging behaviour vary depending on density is a central key to predict their ecological effects when densities increases (Armstrong et al. 1997). Second, density dependent responses in life history traits are the key to understanding population regulation (sensu Messier 1991) in wild mammals, and a number of studies show that vital rates of ungulates are density dependent (reviews in Sæther 1997, Gaillard et al. 2000). Despite this, we still have a limited understanding of the underlying behavioural causes of this density dependence in demographic rates, partly since such data is difficult to obtain. Arguably, density dependence in foraging is the single most important key to understand these processes (Choquenot 1991), though other factors such as territorial behaviour, social stress or higher loads of disease or parasites (Stanko et al. 2002) may play a role in population regulation.

A central issue in foraging theory is that processes may operate at different spatial (and temporal) scales, often viewed as a hierarchy from diet selection at the finest scale, via patch and habitat selection at intermittent scales and up to landscape level (Johnson 1980, Senft et al. 1987). Indeed, sheep are capable of discriminating between food items on a fine spatial scale as well as responding to aggregation of differing forage quality on larger scales (Edwards et al. 1994). From the demographic literature on density dependence, it is evident that the processes involved may well be scale-dependent (Ray and Hastings 1996, Mysterud et al. 2000). At a coarse scale, up to about the scale of daily movement by herbivores (Tyler and Hargrove 1997), density dependent patterns of foraging are predicted by the ideal free distribution theory (IFD; Fretwell and Lucas 1970). Several studies on ungulates have tested whether they conform to these predictions, and results usually suggest rather strong spatial 
structuring (Conradt et al. 1999, Pettorelli et al. 2001, Pettorelli et al. 2002) and therefore a violation of the IFD (but see Wahlström and Kjellander 1995 for roe deer Capreolus capreolus and Ramp and Coulson 2002 for grey kangaroos Macropus giganteus). In whitetailed deer (Odocoileus virginianus), deviations were found around IFD in an experimental setting with two artificial patches (Kohlmann and Risenhoover 1997). Only a few studies, none of them fully experimental, have shown that selection of food items is indeed density dependent (Freeland and Choquenot 1990, Choquenot 1991, Mellado et al. 2003). Feral donkeys (Equus asinus) in Australia ingests an increasingly species-poor diet dominated by a single species of grass (Sehima nervosa) with increasing density, thus elevating intake of crude fibre and getting less nitrogen and mineral nutrients (Freeland and Choquenot 1990). Similar effects from density on diet and demographic variables have been found for domestic goats on heavily grazed pastures in arid grasslands (Mellado et al. 2003). Despite this, no single study has explicitly addressed whether any density dependence in the foraging behaviour of large ungulates is scale dependent or not.

In this fully replicated experimental study at a landscape scale, we aimed to test whether sheep foraging behaviour is density dependent at three levels of scale: from diet selection, via patch selection (within vegetation type selection) to coarse scaled habitat selection (vegetation type). At the three scales considered, foraging processes are likely to dominate, while the landscape scale (i.e. dispersal processes) was not relevant due to our experimental setting. We predict a general inclusion of plant species of poorer nutritional quality, patches and habitats of poorer quality (Borkowski 2000), and therefore also a wider diet with an increase in sheep population density (stocking rate). From the literature on size related differences in foraging behaviour among ungulates (Demment and Van Soest 1985, Illius and Gordon 1987), we predict that lambs will choose a higher quality diet than ewes. 


\section{Material and Methods}

\section{Study area and experimental design}

The experimental area - a $2.7 \mathrm{~km}^{2}$ large enclosure (Fig. 1) - is situated in the Hol municipality in Buskerud County, southern Norway (between $7^{\circ} 55^{\prime}-8^{\circ} 00^{\prime}$ and $60^{\circ} 40^{\prime}-60$ $\left.{ }^{\circ} 45^{\prime}\right)$. There is a sub-continental alpine climate with low to moderate precipitation (7-800 mm, Førland 1993). The bedrock consists of metaarkose (Sigmond 1998), and the soil is moderately base-rich especially in landscape depressions with seepage water (Austrheim et al. 2004). The enclosure is situated in an alpine environment, from 1050 to $1300 \mathrm{~m}$ above sea level, with a terrain typical of alpine environment commonly in use for summer pastures in much of southern Norway. The enclosure is mainly in the lower alpine zone, with a lower border close to the forest line extending upwards into the middle alpine zone. Low shrubs interspersed with grass-dominated meadows dominate the vegetation, and there are only a few scattered birch (Betula sp.) trees in the lowest areas. The area is rich in vascular plant species (i.e. 104 recorded in 180 plots each of $\left.0.25 \mathrm{~m}^{2}\right)$ and herbs dominate (53\%; Austrheim et al. 2004).

The enclosure consisted of a total of $17.3 \mathrm{~km}$ standard sheep fencing (110 cm high). Prior to fencing (summer 2001), grazing pressure by domestic sheep was low $(<10$ sheep per $\mathrm{km}^{2}$ ). Other herbivores such as reindeer (Rangifer tarandus), moose (Alces alces) and roe deer (Capreolus capreolus) can occasionally use part of the area, but are likely to have a negligible effect on the system.

This study is part of a larger study of the ecological impact of sheep grazing on the alpine ecosystem (e.g., Steen et al. 2004, Mysterud et al. 2004). The area is split into nine subenclosures of about $0.3 \mathrm{~km}^{2}$ (some size variation due to practical problems in putting up fencing in areas with bare rock visible), each of three adjacent sub-enclosures has been randomly assigned as controls, low density and high-density areas respectively, to obtain a 
block-wise randomised design with three replications. Each sub-enclosure contains a quite similar amount of the vegetation types (Fig. 1, table 1). Based on the vegetation map (made in 2001), and knowledge of approximate grazing value to the sheep (Rekdal 2001), low-density sub-enclosures were assigned 25 sheep $/ \mathrm{km}^{2}\left(\mathrm{C}, \mathrm{D}\right.$ and I) and high density 80 sheep $/ \mathrm{km}^{2}(\mathrm{~B}, \mathrm{~F}$ and $\mathrm{H}$ ) covering the most typical density range on alpine pastures of Norway (Warren and Mysterud 1995, Mysterud and Mysterud 1999, Mysterud et al. 2002). Habitats with little or no forage (such as water bodies and areas dominated by mosses, rocks, lichens and bogs) were excluded when calculating densities. All sheep were of the most common breed used in Norway, the "Kvit norsk sau" often refereed to as the "Dala" breed, and from the same sheep farmer (Knut-Eirik Sveingard) to insure a similar treatment of all sheep. Ewes averaged $83 \mathrm{~kg}$ in live weight in spring, while lambs grow from an average of $20 \mathrm{~kg}$ to an average of $44 \mathrm{~kg}$ during summer foraging (A. Mysterud, unpubl. data). All sheep were individually tagged with coloured neckbands with a number. The alpine pasture grazing season lasted from last week of June to last week of August, similar to what is used for most mountain regions in southern Norway. No data was collected the first few days, allowing the sheep to habituate to the setting.

\section{Sampling schedule}

Sheep were followed by direct observation using binoculars from June 28 to August 292002. To ensure an unbiased sample without loosing too much in sampling efficiency, we used a stratified randomization of the sequence of registration of individual sheep. The family group was considered to be the smallest independent unit, as the bonds between ewe and lambs are stable, while this breed does not form stable, large herds - rather herd size usually is small and composition varies over short temporal scales in this breed. At the beginning of each day, we randomly selected whether the eastern or western part of the area should be covered, and 
then which sub-enclosure within that part to start in, and from which direction (from above or below). After all ewes in a sub-enclosure had been recorded, we randomly selected a new subenclosure in the chosen half of the research area. Identification of sheep at foraging sites was usually done within 20-50 m, to ensure correct identification of the individual sheep.

At each location (mapped with GPS), we first noted whether the sheep was resting (lying down) or active (grazing), and registered the vegetation type. If the sheep was foraging, we obtained the following additional data after using the binocular to pinpoint us to the specific location of foraging, and when sampling faeces to get individual specific samples:

(1a). Fine scale foraging (plant species/groups) - direction observation. A $1 \mathrm{~m}^{2}$ aluminium square was placed where the observed grazing had taken place - later referred to as a forage site. To get an index of local plant availability, all vascular plants were identified to species except for Salix spp. (S. glauca, S. lapponum, S. lanata) and graminoides (Poaceae, Juncaceae, Cyperaceae). Their respective coverages were estimated on an ordinal scale. To get an index of use, we noted whether bite marks could be observed on any given species. Some groups, such as some graminoids and Salix glauca, S. lapponum and S. lanata with their possible hybrids, were only possibly to determine down to plant group level.

(1b) Fine scale foraging (plant species/groups) - faecal analysis. Faecal samples ( $\mathrm{n}=$ 58) from known individuals were collected in specified quantities over the season to ensure equal representation of densities, ages (lamb vs. adult) and time periods. The samples were frozen, and later used for microhistological analysis (e.g. Stewart and Stewart 1970, Takatsuki 2003, Cortés et al. 2003) by technician Barbro Dahlberg at the Agricultural University of Norway, using a standard procedure ( $1 \mathrm{ml}$ of faeces were boiled in $4 \mathrm{~mm}$ of nitric acid) in which she had considerable previous experience. For each sample, two parallels were run. (2) Intermediate (patch) scale. For every third foraging sites $(\mathrm{n}=102)$, we placed a plot $10 \mathrm{~m}$ away in a random direction and estimated plant availability (coverage). If the 
placement procedure would have taken the random site across a fence or into open water, a new (random) direction was taken from the same foraged site until a valid location was obtained. We term the comparison of the actual foraging site and these "constrained random sites" as patch level selection (Mysterud et al. 1999).

(3) Coarse scale (vegetation types). The vegetation was classified as belonging to one of ten different types. These were usually fairly distinct, and mapped to a scale of about 2 ha following procedures common used by the Norwegian Institute of Land Inventory during the summer of 2001 (Fig. 1). In order to avoid too many missing values in the analysis of vegetation type selection (Aebischer et al. 1993), vegetation types were pooled into the 5 main types (snowbed, bog/fen, meadow, dwarf shrub heath and lichen heath), while the $6^{\text {th }}$ category (water and boulder areas) was removed. The vegetation types were (Fig. 1, table 1):

Moss snowbed: Snowbeds with dominant moss cover that is normally completely free from snow as late as July/August. Water and nutrient availability varies. The short growing season makes it an environment with relatively few vascular plant species, and the vegetation cover is commonly broken up by solifluction. Besides a number of bryophytes typical of this environment, the dominant species is Salix herbacea, together with Sibbaldia procumbens, Carex bigelowii, Gnaphalium supinum, Diphasiastrum alpinum and Ranunculus glacialis.

Grass snowbed: Snowbeds that thaw out before the moss snowbed but after the Dwarf shrub heath, usually at the end of June/start of July. The soil is poor to moderate in nutrients, and water availability is highly variable over the growing season. The vegetation is dominated by graminoids, and is locally dominated by Deschampsia flexuosa. However, Anthoxanthum odoratum, Salix herbacea and Carex bigelowii may also have high coverage. Other common forbs include Alchemilla alpina, Gnaphalium supinum, Bistorta vivipara, Rumex acetosa and Sibbaldia procumbens. 
Stone polygon land: Lichens and ericoids dominate this vegetation type together with Salix herbacea. It exist in small amounts in the upper reaches of the enclosure where the snow cover is moderate but stable, and the substrate fine-grained and often disturbed by solifluction.

Lichen heath: Vegetation type found on ridges and other places with thin, unstable snow cover and considerable wind abrasion. The soil layer is thin and poor in nutrients. Cold, dehydration and abrasion put severe stress on plant communities here. The dominating feature are lichens, while Betula nana, Empetrum nigrum, Loiseluria procumbens, Arctostaphylos uva-ursi, Vaccinium uliginosum, Vaccinium vitis-idaea, Arctostaphylos alpinus and Juncus trifidus are frequent in patches or low-growth forms.

Dwarf shrub heath: Snow cover here is more stable than in lichen heath, but must be mostly thawed out by the end of June. It is varying in soil nutrients and moderate water availability. In this area it is dominated by Betula nana, with Deschampsia flexuosa, Vaccinium myrtillus and Empetrum nigrum in between and in the ground layer together with bryophytes. The amount of forbs is low, but Trientalis europaea, Melampýrum spp. and Solidago virgaurea are common. Where the snow thaws late Betula nana disappears.

Low herb meadow: This species-rich vegetation type supplants the grass snowbed where more nutrients are available, and is intermediate between grass snowbed and tall forb meadow. A mixture of graminoids and low-growing forbs dominate. A poor version typically contains Carex bigelowii, Deschampsia flexuosa, Viola biflora, Taraxacum spp., Veronica alpina, Ranunculus acris and Alchemilla spp. in addition to snowbed species like Salix herbacea, Sibbaldia procumbens, Bistorta vivipara, Alchemilla alpina and Oxýria digyna. Poa alpina, Anthoxanthum odoratum and Agrostis mertensii are also common. More calcareous versions approach tall forb meadow, and contain more of Salix reticulata, 
Thalictrum alpinum, Saxifraga aizoides, Parnassia palustris, Saussurea alpina or lowgrowing Geranium sylvaticum and Ranunculus acris.

Tall herb meadow: The richest vegetation type in the area, occurring where nutrients and water are steadily available and the snow cover is stable but not too late in thawing out. A dense cover of bushes like Salix lapponum and Salix glauca is common, with scattered occurrences of Salix lanata. Common forbs are Geranium sylvaticum and Aconitum septentrionale. Graminoids like Deschampsia caespitosa, D. flexuosa, Agrostis capillaris and Anthoxanthum odoratum commonly achieve high coverage.

Bog: Poor in species and nutrients and dominated by peat mosses. Vascular plants are non-demanding species such as Calluna vulgaris, Empetrum nigrum, Betula nana, Vaccinium uliginosum, Rubus chamaemorus, Eriophorum vaginatum and Carex pauciflora.

Fen: This vegetation type is dominated by Carex spp. and other graminoids and forbs depending on water level and nutrition availability.

Boulder field: Dominated by scree and boulders. The vegetation cover is less than $25 \%$. It occurs only sporadically in the research area (Fig. 1).

\section{Statistical analyses}

\section{Fine scale - plant use}

Diet composition was estimated as proportions. To obtain a measure of the uncertainty in estimations, confidence intervals were obtained by bootstrapping with 1000 resamples (Efron and Tibshirani 1993). We used linear mixed effects models with sheep identity nested within sub-enclosure as a random effect to avoid pseudoreplication (Crawley 2003), and tested whether there was any effect of density, age of sheep and date of observation. For faecal samples, we nested subsample (as two parallels were run) within sheep identity within subenclosure as a random factor. Diet proportions were arcsine(sqrt(observed/100)) transformed 
before analysis to avoid heteroscedasticity. Diet breadth was calculated both overall and separately for each family group using the normalized Levin's measure of niche breadth (Hanski 1978) $\mathrm{B}_{\mathrm{A}}=\left(\left(\sum \mathrm{p}_{\mathrm{i}}^{2}\right)^{-1}-1\right) /(\mathrm{n}-1)$ where $\mathrm{p}_{\mathrm{i}}$ is the predicted dietary proportion of species $\mathrm{i}$, and $\mathrm{n}$ is the total number of forage classes available. We tested for density effects with linear mixed models as above.

\section{Fine scale - plant selection}

Selection is usually defined as use above availability (e.g., Thomas and Taylor 1990), and a number of different methods exist to estimate selection. The definition of what is available can often be crucial for the results obtained, and we therefore assessed plant species/group selection with methods differing mainly in how availability was defined; the first 3 are based on use estimated by direct observation, the last based on use estimated from the faecal analysis. As selection is relative to what is available of other plants, we rank plants rather than giving absolute selection scores (Aebischer et al. 1993).

Method 1. Selection rank for species $\mathrm{x}$ by method 1 , is given by ranking the selection scores $S_{1 x}=g_{x} / n_{x}$ where $g_{x}$ is the number of sites where the species was observed to be foraged upon, and $n_{x}$ is the number of sites where species $\mathrm{x}$ were observed. This predicts the relative dietary contribution $\mathrm{U}_{\mathrm{X}}$ by species $\mathrm{x}, \hat{\mathrm{U}}_{1 \mathrm{x}}$, as $\hat{U}_{1 \mathrm{x}}=\mathrm{S}_{1 \mathrm{x}} \mathrm{c}_{\mathrm{x}} / \Sigma\left(\mathrm{S}_{1} \mathrm{c}\right)$ where $\mathrm{c}_{\mathrm{X}}$ is the relative coverage of species $\mathrm{x}$. Species where no bite marks were observed and species where $\mathrm{n}<5$ were not ranked by this method.

Method 2. Selection rank for species $\mathrm{x}$ by method $2, \mathrm{R}_{2 \mathrm{x}}$, is inferred from $\mathrm{S}_{2 \mathrm{x}}=\left(\operatorname{cg}_{\mathrm{x}} / \mathrm{c}_{\mathrm{x}} \mathrm{g}\right)$ where $\mathrm{c}$ is $\Sigma \mathrm{c}_{\mathrm{x}}$ and $\mathrm{g}$ is $\Sigma \mathrm{g}_{\mathrm{x}}$. The higher the fraction, the higher the selection rank for that species. This predicts the dietary contribution $U_{x}$ by species $x, \hat{U}_{2 x}$ as 
$\hat{U}_{2 x}=S_{2 x} c_{x} / c=\left(\operatorname{cg}_{x} / c_{x} g\right)\left(c_{x} / c\right)=g_{x} / g$. Species where no bite marks were observed and species where $\mathrm{n}<5$ were not ranked by this method.

Method 3. If $\mathrm{c}_{\mathrm{n}, \mathrm{x}}$ is the per cent cover of species $\mathrm{x}$ in site $\mathrm{n}$, and $\beta$ is a bivariate function with values of either +1 , if species $x$ was observed to be grazed in site $n$, and -1 if it was not, for species $\mathrm{x}$ the sum $\varsigma_{\mathrm{x}}=\Sigma\left(\beta \log \left(\mathrm{c}_{\mathrm{n}, \mathrm{x}}\right)\right)$ will give a selection rank score as $\mathrm{S}_{3 \mathrm{x}}=\left(\varsigma_{\mathrm{x}}-\varsigma_{\mathrm{x} \min }\right) /\left(\varsigma_{\max }-\varsigma_{\mathrm{x}} \min \right)$. This makes it quite similar to Ivlev's $\mathrm{E}_{\mathrm{i}}-$ index (Ivlev 1961), and it gives an estimate of the dietary contribution by species $x$ the sum $\varsigma n_{x}=\Sigma\left(\beta \ln \left(c_{n, x}\right)\right)$ will give a rankable selection rank score point estimate as $S_{3 x}=\left(\varsigma_{n, x}-\varsigma_{n, x} \min \right) /\left(\varsigma_{n, \max }-\varsigma_{n, x}\right.$ min). This makes it quite similar to Ivlev's $\mathrm{E}_{\mathrm{i}}$-index (Ivlev 1961), and it gives an estimate of the relative dietary contribution by species $\mathrm{x}$ as $\hat{U}_{3 \mathrm{x}}=\mathrm{S}_{3 \mathrm{X}} \mathrm{c}_{\mathrm{X}} / \Sigma\left(\mathrm{S}_{3 \mathrm{X}} \mathrm{c}_{\mathrm{X}}\right)$. Confidence intervals for $\mathrm{S}_{3 \mathrm{x}}$ and thereby $\hat{\mathrm{U}}_{3 \mathrm{x}}$ were obtained by bootstrapping with 1000 resamples (Efron and Tibshirani 1993).

Faecal analysis. Each species (or group) x from the microhistological analysis were given a selection score $S_{f_{x}}=f_{X} / c_{x}$ where $f_{X}$ is the proportion of total fragments identified as belonging to the species/group.

To test for density-dependent differences in use and selection at species level, we used the diet and selection scores from method 3 at the scale of forage site, and therefore used individual sites with sub-enclosure as a random effect in linear mixed models (Crawley 2003) and density, date and their interaction as candidate explanatory variables. Models were then selected by minimizing of the Akaike's Information Criterion (AIC). The small-sample correction $\mathrm{AIC}_{\mathrm{C}}=\mathrm{AIC}+2 \mathrm{~K}(\mathrm{~K}+1) /(\mathrm{N}-\mathrm{K}+1)$ where $\mathrm{N}$ is the number of observations and $\mathrm{K}$ is the number of regression coefficients including intercept, was applied when $\mathrm{N} / \mathrm{K}<40$. 


\section{Intermediate-scale patch selection}

To assess selection on an intermediate scale, the difference in coverage of various plant species (and also "grazing value" as defined below) between foraging sites and the attached random sites ten $\mathrm{m}$ away were analysed with a paired t-test on the log-transformed coverage data. We did this for the total dataset, then separately for high and low density, and restricted to cases when both foraging and constrained random sites were within the same vegetation type.

\section{Coarse scale - selection of vegetation type}

We assessed habitat (or vegetation type) selection with the compositional analysis method working on log-ratios, and ranking habitats from most to least selected (Aebischer et al. 1993). We used borders of each sub-enclosure to delimit availability for individual family groups. We used the most common habitat as the denominator (Dwarf shrub heath), and avoided problems of missing values by pooling into broader habitat categories (see above). We tested for effects of density (high/low), activity (foraging/resting), season (early/late) within a MANOVA setting (Aebischer et al. 1993).

To assess the role of forage quantity and quality to sheep as a factor in habitat selection, we estimated what we termed "grazing value" for the different vegetation types. This "grazing value" $(\mathrm{G})$ was calculated for each forage site (above) as $\mathrm{G}_{\mathrm{an}}=\Sigma\left(\mathrm{S}_{\mathrm{ax}} \mathrm{c}_{\mathrm{x}, \mathrm{n}}\right)$

(similar to Mysterud et al. 1999), where $\mathrm{S}_{\mathrm{ax}}$ is the selection score for species $\mathrm{x}$ by method a, and $c_{x, n}$ the cover of species $x$ in site $n$, and as $G_{n}^{\prime}=G_{n} h_{n}$ where $h_{n}$ is the vegetation height in site $\mathrm{n}$ to estimate effects of increased biomass in taller vegetation. $\mathrm{G}_{\mathrm{i} \text { mean }}$ and $\mathrm{G}_{\mathrm{i}}{ }^{\prime}$ mean $=$ 
$\left(\mathrm{G}_{1, \mathrm{i}}^{\prime}+\mathrm{G}_{2, \mathrm{i}}^{\prime}+\mathrm{G}_{3, \mathrm{i}}^{\prime}+\mathrm{G}^{\prime} \mathrm{m,i}\right) / \mathrm{m}$ were used as best estimates of forage value for each vegetation type I.

All statistical analysis were done with S-Plus (Crawley 2003), except the compositional analysis, which was done in Microsoft Excel.

\section{Results}

\section{Fine scale - plant species/group use and selection}

The most frequently eaten plant species were D. flexuosa, A. odoratum and Rumex acetosa (Table 2). The overall diet composition estimated by faecal analysis and observational methods was fairly highly correlated (Table 2; Method 1: $r_{\mathrm{pe}}=0.96, P<0.001$; Method 2: $r_{\mathrm{pe}}$ $=0.80, P<0.001 ;$ Method 3: $\left.r_{\mathrm{pe}}=0.94, P<0.001\right)$. As would be expected, woody plants such as Salix spp. were overrepresented in feces. When analyzing how the proportion of the most frequently eaten plant, D. flexuosa, with age, date and density, it turned out that the model including the interaction term between density and date $(\mathrm{AIC}=-180.069)$ was more parsimonious than the additive model with age, density and date $(\mathrm{AIC}=-169.194)$. The use of the most used forage plant, D. flexuosa, increased over the grazing season in high-density, but not in low-density sub-enclosures, and use was higher in ewes than in lambs (Fig. 2). Adding interactions between "age and density" $(\mathrm{AIC}=-164.011)$ or "age and date" $(\mathrm{AIC}=-155.062)$ resulted in poorer models. The parameter estimates were surprisingly similar when performing the same analysis using data from the direct observations, except that the age estimate was less than halved and not quite significant (Table 3). There was no correlation between sheep density and niche breadth $\left(\mathrm{r}_{\mathrm{pe}}=0.06, P=0.30\right)$.

The most highly selected (i.e., when comparing use to availability) forbs were Omalotheca norvegica, Hieracium spp., Saussurea alpina, Taraxacum spp., Solidago virgaurea and Ranunculus acris, together with the grasses Anthoxanthum odoratum and 
Phleum alpinum and the mushrooms (table 2). Least selected were lichens, bryophytes, Vaccinium myrtillus, Empetrum nigrum, Trientalis europeae, Salix lanata and S. herbacea. The species/groups occurring most frequently at forage sites, Empetrum nigrum, Vaccinium myrtillus, R. acetosa, A. odoratum, D. flexuosa, Betula nana, Salix herbacea, lichens and bryophytes, were both among the least and the most highly selected (table 2). The three observational selection estimates were highly correlated (results not shown). Selection for D.flexuosa declined over time in low densities only (interaction date*density; $\mathrm{df}=421, \mathrm{t}=$ $3.180, P=0.022)$.

\section{Intermediate scale - patch selection}

Just 39 of the 102 random sites placed $10 \mathrm{~m}$ away from foraging sites fell within the same vegetation type. When only the 39 pairs within the same vegetation type were used, no single species showed a significant difference between random and foraging sites. There was also a high correlation $\left(r_{\mathrm{Pe}}=0.784, P<0.001\right)$ between plant species coverage at foraging sites and at random sites. This suggests little heterogeneity at this scale - and therefore no strong patch selection within vegetation types. Comparing "grazing values" in random and forage sites within each vegetation type suggests no difference between forage and random sites in the meadow (mean 1.04 vs. $1.02 ; \mathrm{df}=99, \mathrm{t}=0.18, P=0.860$ ), lichen heath (mean 0.31 vs. 0.28 ; $\mathrm{df}=0.39, \mathrm{t}=32, P=0.698)$ and snowbeds $(0.58$ vs. $0.53 ; \mathrm{df}=120, \mathrm{t}=0.63, P=0.528)$, but significantly higher grazing values for forage than random sites in the less selected vegetation types dwarf shrub heath (mean 0.70 vs. 0.47 ; $\mathrm{df}=135, \mathrm{t}=4.15, P<0.001$ ), bog/fen (mean 0.90 vs. $0.55 ; \mathrm{df}=25, \mathrm{t}=3.15, P=0.004)$ and others $(0.39$ vs. $0.04 ; \mathrm{df}=6, \mathrm{t}=9.37, P<$ $0.001)$. 


\section{Coarse-scale foraging: Selection of vegetation types}

Use of vegetation types by sheep in the experimental area differed between resting and foraging behaviour (Pillai-Bartlett trace $=0.544, P<0.001$ ).

Sheep were selective in their use of vegetation types when foraging $\left(\chi^{2}=37.3, P<\right.$ 0.001), but selectivity did not differ due to sheep population density (Pillai-Bartlett trace = $0.179, P=0.147$ ) or season (early vs. late; Pillai-Bartlett trace $=0.165, P=0.189$ ), neither was there any interaction between period and density (Pillai-Bartlett trace $=0.073, P=0.678$ ). Meadow was the most highly selected vegetation type, followed by snowbeds, lichen heath, and bog/fen, while the most common vegetation type in all sub-enclosures, dwarf shrub heath, consistently came out last (Table 4). When estimating mean quantity of forage per vegetation type $\left(\mathrm{G}_{\mathrm{i} \text { mean }}\right)$, the meadow habitat clearly had the most forage. For the other habitats, estimates were more similar (and about half that of meadow), and there was no relationship between forage quantity and overall habitat ranking by sheep $(\mathrm{n}=5, \mathrm{r}=-0.12, P>0.8)$.

Sheep were also selective in their use of vegetation types chosen for resting sites $\left(\chi^{2}=\right.$ 48.9, $P<0.001)$. Lichen heath was the highest ranked for resting, and significantly higher ranked than dwarf shrub heath $(t=2.94, P=0.003)$. Bog/fen was not recorded as used for resting, while snowbed and meadow was used roughly according to availability.

\section{Discussion}

Although there is an extensive literature on density dependence in demographic variables for ungulates in general (see Introduction), little is known about the proximate mechanisms behind these effects. In this study, we show that although foraging by sheep was non-random at all scales, the density-dependent response in foraging behaviour was scale-dependent. At a coarse (habitat) and intermediate (patch) scale, selection of different vegetation types or sites within vegetation sites did not differ significantly depending on density. However, at the 
finest scale, use of plant species was markedly density dependent. Use of the abundant grass Deschampsia flexuosa increased as the grazing season progressed in high density subenclosures only (Fig. 2). Since there was no density dependence in the selection of vegetation type (see Burboa-Cabrera et al. 2003 for a similar result in cattle), the density dependent food choice is likely a small scale process. Sheep have been shown to act less selectively on a fine scale when less satiated (Edwards et al. 1994), which may on a proximate level explain this change in diet with food limitation at high density. The current study was short-term (one year of grazing in a previously lightly grazed area), and it remains to be determined whether the same conclusion applies to areas with a long-term difference in grazing pressure.

The density dependence observed in diet was robust to the methodology used, as both observational and microhistological analyses of diet composition yielded similar results. However, the absolute values obtained by these two methods may differ, as faecal analyses tend to underestimate the proportion of easily digestible plants such as many forbs, while grasses and especially shrubs may be overestimated (Stewart and Stewart 1970, Kessler et al. 1981, Mofareh et al. 1997, Henley et al. 2001). On the other hand, it can be very difficult to obtain unbiased estimates by direct observation, as some plants are removed completely, leaving no observable bite marks. Indeed, graze marks on Deschampsia flexuosa were often difficult to detect, while big-leaved forbs and grasses like Geranium sylvaticum and $A$. odoratum probably represent the other extreme. None the less, in general, the selection scores from the observational methods were rather closely correlated with the ones obtained from faecal analysis (table 2).

Selection at the intermediate (patch) scale seemed to occur only in heterogenous vegetation types. There were no differences between grazing values in grazed and random sites (10 $\mathrm{m}$ away) in meadow, lichen heath and snowbed habitat types, but significant difference in the vegetation types less frequently used for foraging, namely dwarf shrub heath, 
bog/fen and boulder fields. This suggests a greater spatial heterogeneity in terms of grazing value in poorer vegetation types, resulting in patch selection.

At the coarsest spatial scale, selection differed depending on activity. Meadow was clearly the most highly selected vegetation type for foraging by sheep, and the estimated "grazing values" can account for the high selection of the meadow types - this is typically the best grazing areas in the mountains (Rekdal 2001). If sheep were distributed only according to an ideal free distribution (IFD), we would expect the grazing pressure to be proportional to the amount of forage available in each vegetation type and/or density dependent selection. The experimental scale is theoretically suitable (i.e., scale of daily movements) for an IFD to be observed (Tyler and Hargrove 1997). However, selection of vegetation types were not density dependent, as predicted from the IFD. Further, snowbeds were grazed considerably more than their proportions of available forage indicate, while dwarf shrub heath less than expected from "grazing value". Differences in plant quality, which likely are very high in snow beds as newly emergent forage may be available as the snow is melting later here, may partly account for this. Note that this mainly applies to the grass snow beds, while there is very little forage in the moss snow beds. Lichen heath, containing little forage, was observed to be highly preferred for resting. Lichen heaths are typical on ridges, and choice of such a position for resting have been suggested to be the remnant of an antipredator tactic (Warren and Mysterud 1991, Warren et al. 1993), as for example bighorn sheep (Ovis canadensis) show a similar behaviour.

Sheep have the ability to utilize grass forage resources in landscapes too poor to use for more intensive agricultural purposes, and sheep husbandry is a cornerstone of the economy in many rural areas of Norway (Drabløs 1997). During the summer months, some 22.5 million sheep are released onto outlying pastures in Norway; making it the by far most common large herbivore. Alpine habitats constitute about $50 \%$ of the area of Norway and 
have been used for grazing since the Bronze Age (Kvamme 1988). Despite this, the knowledge of the foraging ecology of domestic sheep is poor, and no study has earlier addressed whether or how population density may affect this. Densities in our experiment is within the density range for sheep grazing in similar alpine habitats of Norway (Mysterud \& Mysterud, 1999), and are considered sustainable by sheep farmers in the sense that any loss from lower individual meat yield or higher mortality is expected to be more than offset by the benefit of increased total yield when increasing density within this range. This suggests that eventual density-dependent effects on foraging behaviour are non-extreme and may be hard to detect, but will have direct relevance to management of the commons used for sheep forage. Our study provides evidence that density dependence in foraging behaviour occurs, but only at the finest spatial scale (diet choice). With an increase in sheep density, not only is an increasing number of sheep eating more, but they also eat a larger proportion of $D$. flexuosa. This thus provides a case showing that the ecological impact of grazers on plant population may not be linearly related to herbivore density, which is a result with broad implications both for basic as well as applied ecology.

\section{Acknowledgements}

This experiment was funded by the Research Council of Norway (Project no. 134361/720), Tiltaksfondet for småfe- og fjørfe m.m., Grunneigarfondet, Directorate for Nature Management, Buskerud Landbruksselskap, BU-funds from Aust-Agder, Buskerud, Telemark and Vest-Agder counties, and municipalities Bykle, Eidfjord, Gjesdal, Hol, Hægebostad, Kvinesdal, Nore og Uvdal, Tinn, Sirdal, Suldal, Ulvik and Vinje, to whom we are grateful. We thank Knut-Eirik Sveingard, Ragnhild Vikesland, Erling Skurdal and all landowners for their valuable support. We thank Barbro Dahlberg for performing the faecal analyses, and Marianne Evju for assistance in botanical systematics. 


\section{References}

Aebischer, N. J., Robertson, P. A. and Kenward, R. E. 1993. Compositional analysis of habitat use from animal radio-tracking data. - Ecology 74: 1313-1325.

Armstrong, H. M., Gordon, I. J., Hutchings, N. J., Illius, A. W., Milne, J. A. and Sibbald, A. R. 1997. A model of the grazing of hill vegetation by sheep in the UK. II. The prediction of offtake by sheep. - J Appl Ecol 34: 186-207.

Austrheim, G., Evju, M. and Mysterud, A. 2004. Herb abundance and life history traits in two contrasting alpine habitats in southern Norway. - Plant Ecology: initially accepted.

Borkowski, J. 2000. Influence of the density of a sika deer population on activity, habitat use, and group size. - Can J Zool 78: 1369-1374.

Burboa-Cabrera, F. R., Schacht, W. H. and Anderson, B. E. 2003. Utilization and grazing distribution of cattle at 4 stocking densities. - J Range Manage 56: 328-333.

Choquenot, D. 1991. Density-dependent growth, body condition, and demography in feral donkeys: testing the food hypothesis. - Ecology 72: 805-813.

Conradt, L., Clutton-Brock, T. H. and Guinness, F. E. 1999. The relationship between habitat choice and lifetime reproductive success in female red deer. - Oecologia 120: 218-224.

Cortés, A., Miranda, E., Rau, J. R. and Jiménez, J. E. 2003. Feeding habits of guanacos Lama guanicoe in the high Andes of north-central Chile. - Acta Theriol 48: 229-237.

Crawley, M. J. 2003. Statistical computing. An introduction to data analysis using S-Plus. Jon Wiley and Sons.

Demment, M. W. and Van Soest, P. J. 1985. A nutritional explanation for body-size patterns of ruminant and nonruminant herbivores. - Am Nat 125: 641-672.

Drabløs, D. 1997. The story of the Norwegian sheep. Anniversary review of the Norwegian Sheep and Goat Breeders 1947-1997. - Norwegian Sheep and Goat Breeders. 
Edwards, G. R., Newman, J. A., Parsons, A. J. and Krebs, J. R. 1994. Effects of the scale and spatial distribution of the food resource and animal state on diet selection: an example with sheep. - J Anim Ecol 63: 816-826.

Efron, B. and Tibshirani, R. J. 1993. An introduction to the bootstrap. - Chapman and Hall.

Førland, E. J. 1993. Precipitation normals, period 1961-1990. - Norwegian Metrological institute 39: 1-63.

Freeland, W. J. and Choquenot, D. 1990. Determinants of herbivore carrying capacity: plants, nutrients, and Equus asinus in northern Australia. - Ecology 71: 589-597.

Fretwell, S. D. and Lucas, H. L. j. 1970. On territorial behavior and other factors influencing habitat distribution in birds. I. Theoretical development. - Acta Biotheor 19: 16-36.

Gaillard, J.-M., Festa-Bianchet, M., Yoccoz, N. G., Loison, A. and Toigo, C. 2000. Temporal variation in fitness components and population dynamics of large herbivores. - Ann Rev Ecol Syst 31: 367-393.

Hanski, I. 1978. Some comments on the measurement of niche metrics. - Ecology 59: 168174.

Henley, S. R., Smith, D. G. and Raats, J. G. 2001. Evaluation of 3 techniques for determining diet composition. - J Range Manage 54: 582-588.

Hobbs, N. T. 1996. Modification of ecosystems by ungulates. - J Wildl Manage 60: 695-713.

Illius, A. W. and Gordon, I. J. 1987. The allometry of food intake in grazing ruminants. - J Anim Ecol 56: 989-999.

Ivlev, V. S. 1961. Experimental ecology of the feeding fishes. - Yale University Press.

Jefferies, R. L., Klein, D. R. and Shaver, G. R. 1994. Vertebrate herbivores and northern plant communities: reciprocal influences and responses. - Oikos 71: 193-206.

Johnson, D. H. 1980. The comparison of usage and availability measurements for evaluating resource preference. - Ecology 61: 65-71. 
Kessler, W. B., Kasworm, W. F. and Bodie, W. L. 1981. Three methods compared for analysis of pronghorn diets. - J Wildl Manage 45: 612-619.

Kohlmann, S. G. and Risenhoover, K. L. 1997. White-tailed deer in a patchy environment: a test of the ideal-free-distribution theory. - J Mammal 78: 1261-1272.

Kvamme, M. 1988. Pollen analytical studies of mountain summer farming in Western Norway. - In: Birks, H. H., Birks, H. J. B., Kaland, P. E. and Moe, D. (eds.), The Cultural landscape, past, present and future. Cambridge University Press, pp. 349-367.

Mellado, M., Valdez, R., Lara, L. M. and Lopez, R. 2003. Stocking rate effects on goats: A research observation. - J Range Manage 56: 167-173.

Messier, F. 1991. The significance of limiting and regulating factors on the demography of moose and white-tailed deer. - J Anim Ecol 60: 377-393.

Mofareh, M. M., Bech, R. F. and Schneberger, A. G. 1997. Comparing techniques for determining steer diets in northern Chihuahuan Desert. - J Range Manage 50: 27-32.

Mysterud, A., Hansen, L. O., Peters, C. and Austrheim, G. 2004. The short-term effect of sheep grazing on invertebrates (Diptera and Hemiptera) relative to other environmental factors in an alpine ecosystem. - Ecography submitted ms..

Mysterud, A., Langvatn, R., Yoccoz, N. G. and Stenseth, N. C. 2002. Large-scale habitat variability, delayed density effects and red deer populations in Norway. - J Anim Ecol 71: $569-580$

Mysterud, A., Lian, L.-B. and Hjermann, D. Ø. 1999. Scale-dependent trade-offs in foraging by European roe deer (Capreolus capreolus) during winter. - Can J Zool 77: 14861493.

Mysterud, A. and Mysterud, I. 1999. Bærekraftig bruk og forvaltning av Setesdals Vesthei og Ryfylkeheiene. En utredning med spesiell vekt på økologiske effekter av husdyrbeiting i utmark. - Utmarksnæring i Norge 1-99: 1-197. 
Mysterud, A., Yoccoz, N. G., Stenseth, N. C. and Langvatn, R. 2000. Relationships between sex ratio, climate and density in red deer: the importance of spatial scale. - J Anim Ecol 69: 959-974.

Pettorelli, N., Gaillard, J.-M., Duncan, P., Ouellet, J.-P. and Van Laere, G. 2001. Population density and small-scale variation in habitat quality affect phenotypic quality in roe deer. - Oecologia 128: 400-405.

Pettorelli, N., Gaillard, J.-M., Van Laere, G., Duncan, P., Kjellander, P., Liberg, O., Delorme, D. and Maillard, D. 2002. Variations in adult body mass in roe deer: the effects of population density at birth and of habitat quality. - Proc R Soc Lond Ser B 269: 747753.

Ramp, D. and Coulson, G. 2002. Density dependence in foraging habitat preference of eastern grey kangaroos. - Oikos 98: 393-402.

Ray, C. and Hastings, A. 1996. Density dependence: are we searching at the wrong spatial scale? - J Anim Ecol 65: 556-566.

Rekdal, Y. 2001. Husdyrbeite i fjellet: vegetasjonstypar og beiteverdi. NIJOS-rapport; 7/01. Norsk institutt for jord- og skogkartlegging.

Sæther, B.-E. 1997. Environmental stochasticity and population dynamics of large herbivores: a search for mechanisms. - Trends Ecol Evol 12: 143-149.

Senft, R. L., Coughenour, M. B., Bailey, D. W., Rittenhouse, L. R., Sala, O. E. and Swift, D. M. 1987. Large herbivore foraging and ecological hierarchies. - BioScience 37: 789799.

Sigmond, E. 1998. Odda map of rock; Odda; 1:250 000. - Norwegian Geological Surveys. Stanko, M., Miklisová, D., de Bellocq, J. G. and Morand, S. 2002. Mammal density and patterns of ectoparasite species richness and abundance. - Oecologia 131: 289-295. 
Steen, H., Mysterud, A. and Austrheim, G. 2004. Sheep grazing and rodent population dynamics: evidence of negative interactions from a fully replicated, landscape scale experiment. - Oecologia submitted ms..

Stewart, D. R. M. and Stewart, J. 1970. Food preference data by faecal analysis for African plains ungulates. - Zoologica Africana 15: 115-129.

Takatsuki, S. 2003. Use of mires and food habits of sika deer in the Oze Area, central Japan. Ecol Res 18: 331-338.

Thomas, D. L. and Taylor, E. J. 1990. Study design and tests for comparing resource use and availability. - J Wildl Manage 54: 322-330.

Tyler, J. A. and Hargrove, W. W. 1997. Predicting spatial distribution of foragers over large resource landscapes: a modeling analysis of the Ideal Free Distribution. - Oikos 79: 376-386.

Wahlström, L. K. and Kjellander, P. 1995. Ideal free distribution and natal dispersal in female roe deer. - Oecologia 103: 302-308.

Warren, J. T. and Mysterud, I. 1991. Summer habitat use and activity patterns of domestic sheep on coniferous range in southern Norway. - J Range Manage 44: 2-6.

Warren, J. T. and Mysterud, I. 1995. Sau, villrein og ressursbruk på Hardangervidda i tidligere tid og nå. En utredning med særlig vekt på dagens problemer for beitebruk og villreinforvaltning i lokalt og regionalt perspektiv. - Biologisk institutt, Universitetet i Oslo.

Warren, J. T., Mysterud, I., Stensli, O. M., Berg, M. and Movik, E. 1993. Use of forest vegetation by sheep as recorded by radio telemetry. - Acta Agric Scandinavica; Sec A. Anim Sci 43: 190-192. 
Table 1. Distribution of vegetation types over the sub-enclosures containing sheep (B, C and I with low density, B, F and $\mathrm{H}$ with high density of sheep). Note that not all vegetation types were recorded by the survey in all areas (resolution $2 \mathrm{ha}$ ), but smaller patches could still be found during observation of forage selection in each of the sub-enclosures. How vegetation types were pooled in the compositional analyses is indicated by dotted lines.

\begin{tabular}{|c|c|c|c|c|c|c|c|c|c|c|c|c|}
\hline \multirow[t]{2}{*}{ Vegetation type } & \multicolumn{2}{|c|}{ B } & \multicolumn{2}{|c|}{$\mathrm{C}$} & \multicolumn{2}{|c|}{$\mathrm{D}$} & \multicolumn{2}{|c|}{$\mathrm{F}$} & \multicolumn{2}{|c|}{$\mathrm{H}$} & \multicolumn{2}{|c|}{ I } \\
\hline & daa & $\%$ & daa & $\%$ & daa & $\%$ & daa & $\%$ & daa & $\%$ & daa & $\%$ \\
\hline Moss snowbed & 3.2 & 1.0 & 1.5 & 0.4 & & & 0.2 & 0.1 & & & & \\
\hline Grass snowbed & 38.1 & 12.1 & 69.9 & 20.6 & 29.4 & 7.7 & 16.0 & 7.2 & 17.3 & 7.1 & 42.1 & 18.2 \\
\hline Stone polygon land & 9.9 & 3.1 & 17.7 & 5.2 & 6.3 & 1.6 & 1.3 & 0.6 & & & & \\
\hline Lichen heath & 72.0 & 22.9 & 62.6 & 18.5 & 62.3 & 16.2 & 21.2 & 9.6 & 32.5 & 13.4 & 54.9 & 23.8 \\
\hline Dwarf shrub heath & 152.9 & 48.6 & 143.3 & 42.2 & 213.6 & 55.6 & 122.9 & 55.7 & 161.5 & 66.7 & 117.6 & 50.9 \\
\hline Low herb meadow & & & & & 25.5 & 6.6 & 13.0 & 5.9 & & & & \\
\hline Tall herb meadow & 19.0 & 6.0 & 15.6 & 4.6 & 25.3 & 6.6 & 35.6 & 16.1 & 14.6 & 6.0 & 13.7 & 5.9 \\
\hline Bog & 0.4 & 0.1 & 2.2 & 0.6 & & & & & & & & \\
\hline Fen & 10.1 & 3.2 & 26.4 & 7.8 & 21.8 & 5.7 & 10.6 & 4.8 & 14.6 & 6.0 & 2.8 & 1.2 \\
\hline Boulder field & 8.0 & 2.5 & & & & & & & & & & \\
\hline Water bodies & 1.0 & 0.3 & & & & & & & 1.6 & 0.7 & & \\
\hline Total & 305.6 & 100.0 & 339.2 & 100.0 & 384.2 & 100.0 & 220.8 & 100.0 & 240.5 & 100.0 & 231.1 & 100.0 \\
\hline
\end{tabular}


Table 2. Diet composition of free-ranging sheep in Hol, Norway, summer 2002, estimated by microhistological analysis of faeces and by 3 related observational methods (see text for details). Estimates of availability refers to ground coverage, while selection rank is based on selection scores, which is mean of dietary contribution estimates/availability in random sites (thus, a selection score of 1 would indicate proportional use). A 95\% confidence interval was established for faecal samples by bootstrapping.

\begin{tabular}{|c|c|c|c|c|c|c|c|c|c|}
\hline \multirow[t]{2}{*}{ Plant group/species } & \multicolumn{3}{|c|}{$\begin{array}{c}\text { Diet }(\%) \\
\text { - Faecal samples }\end{array}$} & \multicolumn{3}{|c|}{$\begin{array}{c}\text { Diet (\%) } \\
\text {-Observational methods }\end{array}$} & \multirow{2}{*}{$\begin{array}{l}\text { Available } \\
\text { (\%, forage } \\
\text { sites) }\end{array}$} & \multirow{2}{*}{$\begin{array}{l}\text { Available } \\
(\%, \\
\text { random } \\
\text { sites })\end{array}$} & \multirow{2}{*}{$\begin{array}{c}\text { Selection } \\
\text { rank } \\
\text { (selection } \\
\text { score) } \\
\end{array}$} \\
\hline & Mean & $\begin{array}{c}95 \% \\
\text { Lower } \\
\text { CL }\end{array}$ & $\begin{array}{c}95 \% \\
\text { Upper } \\
\text { CL }\end{array}$ & $\hat{\mathrm{U}}_{1}$ & $\hat{\mathrm{U}}_{2}$ & $\hat{\mathrm{U}}_{3}$ & & & \\
\hline Graminoids & 56.9 & 51.8 & 62.8 & 49.9 & 40.8 & 43.9 & 24.6 & 22.4 & $1(2.3)$ \\
\hline Agrostis capillaris & 0.5 & 0.4 & 0.6 & 0.3 & 0.3 & 0.3 & 0.2 & 0.3 & $21(1.3)$ \\
\hline Anthoxanthum odoratum & 0.4 & 0.3 & 0.5 & 10.0 & 10.8 & 7.7 & 3.3 & 2.3 & $15(2.2)$ \\
\hline Carex spp. & 9.3 & 8.3 & 10.4 & 5.3 & 6.1 & 5.3 & 3.0 & 3.7 & $17(2.0)$ \\
\hline Other Cyperaceae & 0.4 & 0.3 & 0.5 & 0.1 & 0.1 & 0.1 & 0.1 & 0.7 & $25(0.4)$ \\
\hline Deschampsia flexuosa & 30.7 & 28.9 & 32.7 & 25.3 & 12.4 & 20.6 & 10.5 & 8.3 & $10(3.0)$ \\
\hline Deschampsia caespitosa & 1.5 & 1.3 & 1.8 & 2.3 & 1.8 & 1.8 & 1.5 & 1.2 & $19(1.5)$ \\
\hline Festuca sp. & 1.2 & 1.0 & 1.3 & 0 & 0 & 0.2 & 0.5 & 0.1 & $7(6.2)$ \\
\hline Festuca rubra & 0.5 & 0.4 & 0.7 & 0.1 & 0.2 & 0.0 & 0.1 & 0.5 & $23(0.6)$ \\
\hline Milium effusum & 0.2 & 0.2 & 0.4 & 0.3 & 0.3 & 0.1 & 0.1 & 0 & \\
\hline Molinia caerulea & 0.6 & 0.4 & 0.7 & 0 & 0 & 0 & 0 & 0 & \\
\hline Nardus stricta & 1.8 & 1.5 & 2.1 & 0.6 & 0.4 & 1.3 & 2.1 & 2.4 & $24(0.5)$ \\
\hline Poa spp. & 2.8 & 2.3 & 3.2 & 0.5 & 0.9 & 0.6 & 0.2 & 0.4 & $8(4.3)$ \\
\hline Phleum alpinum & 0.9 & 0.7 & 1.1 & 1.2 & 2.5 & 1.3 & 0.5 & 0.5 & $14(2.6)$ \\
\hline Other graminoids & 6.2 & 5.9 & 6.7 & 3.8 & 4.8 & 4.6 & 2.6 & 2.0 & $13(2.7)$ \\
\hline Forbs & 22.2 & 20.7 & 23.7 & 28.9 & 47.0 & 28.2 & 20.7 & 13.1 & $2(2.2)$ \\
\hline Alchemilla spp. & - & - & - & 2.3 & 2.5 & 2.8 & 2.7 & 1.7 & $19(1.5)$ \\
\hline Geranium sylvaticum & - & - & - & 6.3 & 4.3 & 4.7 & 3.2 & 1.8 & $12(2.8)$ \\
\hline Hieracium spp. & - & - & - & 0.9 & 3.2 & 0.7 & 0.3 & 0.2 & $5(8.0)$ \\
\hline Omalotheca norvegica & - & - & - & 0.8 & 2.3 & 0.4 & 0.3 & 0.4 & $11(2.9)$ \\
\hline Ranunculus acris & - & - & - & 1.4 & 3.3 & 1.1 & 0.7 & 0.9 & $16(2.2)$ \\
\hline Rumex acetosa & - & - & - & 5.1 & 7.5 & 5.0 & 2.4 & 2.2 & $13(2.7)$ \\
\hline Saussurea alpina & - & - & - & 1.2 & 2.9 & 0.8 & 0.4 & 0.2 & $4(8.2)$ \\
\hline Sibbaldia procumbens & - & - & - & 0.7 & 1.3 & 1.0 & 0.8 & 0.3 & $9(3.3)$ \\
\hline Solidago virgaurea & - & - & - & 1.3 & 2.9 & 0.9 & 0.4 & 0.05 & $2(34.0)$ \\
\hline Taraxacum spp. & - & - & - & 1.2 & 3.6 & 0.9 & 0.5 & 0.3 & $6(6.3)$ \\
\hline Other forbs & - & - & - & 7.6 & 13.2 & 10.0 & 8.9 & 5.2 & $18(2.0)$ \\
\hline Woody plants & 20.1 & 17.6 & 23.1 & 19.2 & 8.8 & 23.9 & 38.3 & 41.4 & $3(0.5)$ \\
\hline Betula spp & 1.2 & 0.9 & 1.7 & 6.4 & 1.8 & 5.0 & 8.2 & 9.1 & $26(0.3)$ \\
\hline Pinus sylvestris & 0.02 & 0.01 & 0.06 & 0 & 0 & 0 & 0 & 0 & \\
\hline
\end{tabular}




\begin{tabular}{|c|c|c|c|c|c|c|c|c|c|}
\hline Salix herbacea & 0.9 & 0.7 & 1.2 & 2.9 & 1.3 & 4.6 & 7.3 & 5.4 & $25(0.4)$ \\
\hline Salix spp. & 16.0 & 14.3 & 17.9 & 5.3 & 2.3 & 4.5 & 7.9 & 7.0 & $20(1.4)$ \\
\hline Vaccinium uligonosum & - & - & 0.0 & 0.3 & 0.3 & 1.1 & 2.3 & 2.9 & $27(0.2)$ \\
\hline Vaccinium myrtillus & 1.5 & 1.3 & 1.7 & 1.2 & 0.9 & 2.2 & 4.7 & 5.7 & $26(0.3)$ \\
\hline Calluna vulgaris & 0.5 & 0.4 & 0.6 & 0 & 0 & 0 & 0 & 0 & \\
\hline Empetrum nigrum & - & - & - & 0.6 & 0.4 & 2.7 & 5.0 & 8.4 & $28(0.2)$ \\
\hline Other woody plants & - & - & - & 2.4 & 1.8 & 3.8 & 2.9 & 2.9 & $22(0.9)$ \\
\hline Other & 0.7 & 0.5 & 1.1 & 2.1 & 3.4 & 3.7 & 12.0 & 17.3 & $4(0.1)$ \\
\hline Equisetum spp. & 0.3 & 0.2 & 0.5 & 0 & 0 & 0.01 & 0.01 & 0.02 & $3(8.4)$ \\
\hline Mushrooms & - & - & - & 1.7 & 3.2 & 0.8 & 0.30 & 0.02 & $1(47.5)$ \\
\hline Lichens & 0.1 & 0.1 & 0.2 & 0.3 & 0.2 & 1.4 & 4.4 & 5.8 & $28(0.1)$ \\
\hline Bryophytes & 0.3 & 0.2 & 0.4 & - & - & 1.5 & 11.6 & 17.3 & $29(0.02)$ \\
\hline
\end{tabular}


Table 3. Results from linear mixed effects models analysing how the proportion of

Deschampsia flexuosa, the dominant feeding plant in the diet (estimated by fecal analysis and direct observation), changes as a function of age, density and date.

\begin{tabular}{lclrrr}
\hline Parameter & \multicolumn{1}{c}{ L.s. } & SE & df & $\mathrm{t}$ & $P$ \\
& mean & & & & \\
\hline A. Fecal analysis & & & & & \\
Intercept & -0.2051 & 0.1269 & 44 & -1.617 & 0.113 \\
Age & 0.1032 & 0.0330 & 37 & 3.124 & 0.004 \\
Julian date & 0.0038 & 0.0006 & 26 & 6.461 & $<0.001$ \\
Density & 0.7027 & 0.1559 & 4 & 4.508 & 0.011 \\
Density & -0.0039 & 0.0007 & 26 & -5.365 & $<0.001$ \\
B. Direct observation & & & & \\
Intercept & -0.1880 & 0.1930 & 246 & -0.974 & 0.331 \\
Age & 0.0390 & 0.0243 & 58 & 1.606 & 0.114 \\
Julian date & 0.0017 & 0.0009 & 246 & 1.842 & 0.067 \\
Density & 0.6672 & 0.2923 & 4 & 2.282 & 0.085 \\
Density & -0.0033 & 0.0014 & 246 & -2.441 & 0.015 \\
\hline
\end{tabular}


Table 4. Vegetation type selection by foraging sheep in Hol, Norway, during summer 2002, as determined by the compositional analysis, and per cent observations vs. per cent available (mean for all three sub-enclosures of a given density). There was no effect on density (Low $=$ low density; High = high density) on habitat ranking.

\begin{tabular}{|c|c|c|c|c|c|c|c|c|}
\hline \multirow[t]{2}{*}{ Vegetation type } & \multicolumn{2}{|c|}{$\begin{array}{l}\text { Vegetation type } \\
\text { ranking }\end{array}$} & \multicolumn{2}{|c|}{ Use } & \multicolumn{2}{|c|}{ Available } & \multicolumn{2}{|c|}{ Selection } \\
\hline & Grazing & Resting & Low & High & Low & High & Low & High \\
\hline $\begin{array}{l}\text { Low/tall herb } \\
\text { meadow }\end{array}$ & 1 & 3 & 24.5 & 28.7 & 7.9 & 11.4 & 3.1 & 2.52 \\
\hline $\begin{array}{l}\text { Moss/grass } \\
\text { snowbed/stone } \\
\text { polygon land }\end{array}$ & 2 & 4 & 34.6 & 25.6 & 17.9 & 10.5 & 1.93 & 2.44 \\
\hline Lichen heath & 3 & 1 & 10.7 & 5.5 & 19.5 & 15.4 & 0.55 & 0.36 \\
\hline Bog/fen & 4 & 5 & 4.4 & 4.9 & 5.1 & 4.7 & 0.86 & 1.03 \\
\hline Dwarf shrub heath & 5 & 2 & 25.8 & 35.4 & 49.6 & 57.2 & 0.52 & 0.62 \\
\hline
\end{tabular}




\section{Figure captions}

Figure 1. Vegetation type map of the experimental area in Hol, Norway. The 9 subenclosures (black lines are fences) is named A to I from left to right (see table 1). Sub-

enclosures B, F and H have a high sheep density ( 80 sheep per $\mathrm{km}^{2}$ ), while $\mathrm{C}, \mathrm{D}$ and I have a low sheep density ( 25 sheep per $\mathrm{km}^{2}$ ).

Figure 2. The proportion of Deschampsia flexuosa in the diet (based on faecal samples) over the summer grazing season for ewes and lambs at high and low density. 


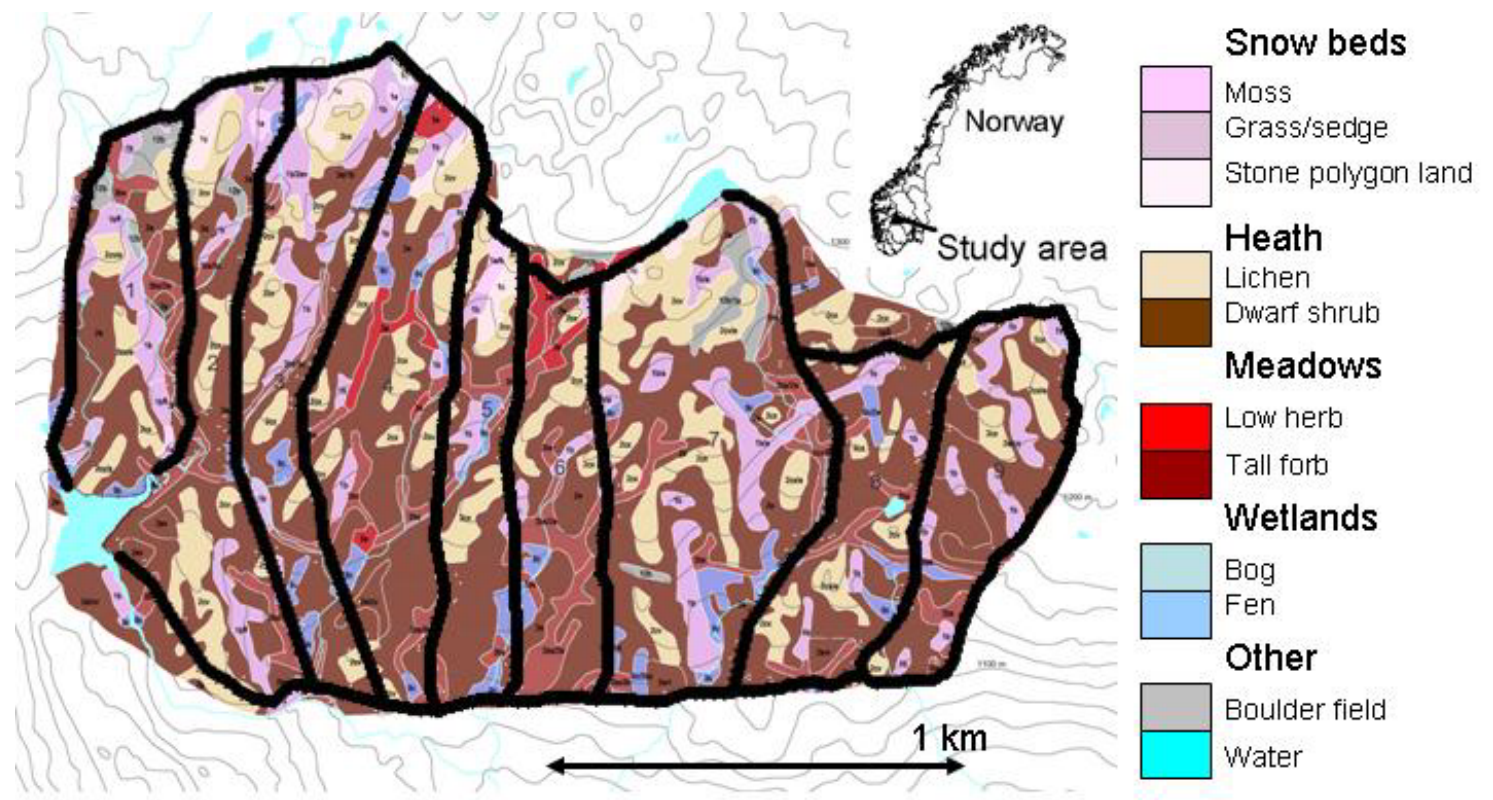

Figure 1 


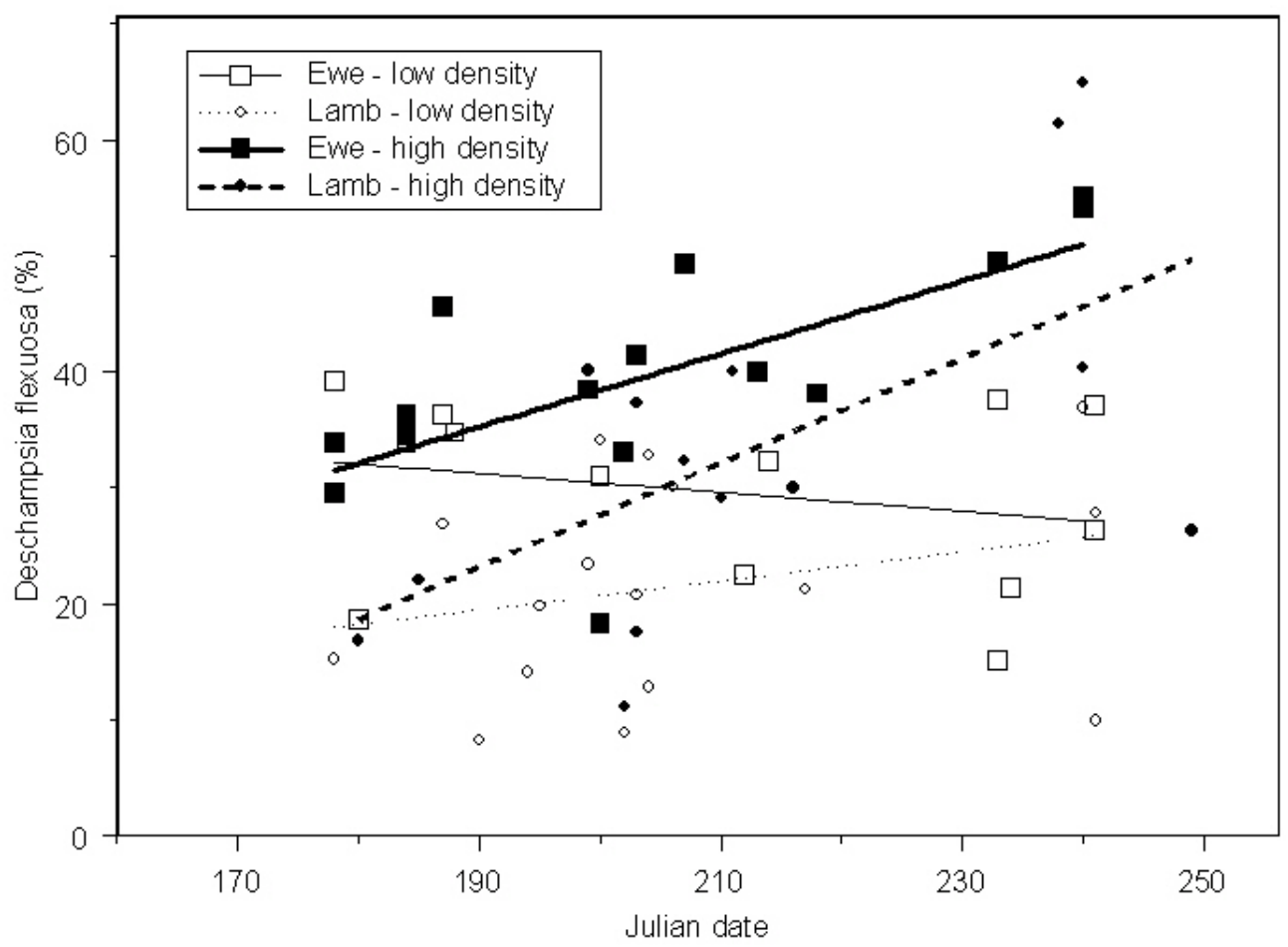

Figure 2 